\title{
RELATIONSHIP OF A TRYPSIN-LIKE ENZYME IN RABBIT SPERMATOZOA TO CAPACITATION
}

\author{
L. J. D. ZANEVELD, P. N. SRIVASTAVA AND W. L. WILLIAMS \\ Department of Biochemistry, University of Georgia, \\ Athens, Georgia 30601, U.S.A. \\ (Received 28th April 1969, revised 26th Fune 1969)
}

\begin{abstract}
Summary. The existence of a trypsin-like enzyme (TLE) in acrosomes of epididymal spermatozoa was confirmed and was further demonstrated to be present in acrosomes of ejaculated and capacitated spermatozoa. TLE rapidly removes the zona pellucida of the ovum. Extracts of acrosomes of ejaculated spermatozoa contain an inhibitor that is separated from the TLE by purification of the TLE.

The inhibitor of TLE is also present in seminal plasma. This enzymeenzyme inhibitor relationship appears analogous to the corona-removing enzyme-decapacitation factor relationship and part of capacitation very likely involves removal of the inhibitor from TLE and decapacitation factor from the corona-removing enzyme. TLE is inhibited by soybean trypsin inhibitor and less effectively by mercaptoethanol.
\end{abstract}

Yamane $(1935 \mathrm{a}, \mathrm{b})$ showed that canine sperm extracts obtained by toluene treatment had the ability to remove the external layers of ova and contained a trypsin-like enzyme (TLE). Buruiana (1956) also reported the presence of trypsin activity in spermatozoa of several species.

Hartree \& Srivastava (1965) and Srivastava, Adams \& Hartree (1965) described an acrosomal enzyme preparation from ram spermatozoa that removed the corona and zona pellucida from rabbit ova. Using essentially the same technique, Zaneveld, McRorie \& Williams (1968) confirmed these results using rabbit sperm acrosomes and showed that removal of the corona by acrosomal extracts was inhibited by decapacitation factor (DF) preparations.

Stambaugh \& Buckley (1968) extracted a TLE from epididymal sperm acrosomes that removed the zona pellucida from rabbit ova. Zaneveld, McRorie \& Williams (1969) did not find a TLE in the acrosomal extracts of ejaculated spermatozoa employing the method of Hartree \& Srivastava (1965). On further fractionation of these extracts by DEAE-column chromatography, TLE activity was found in one of the eluted protein peaks. This peak also possessed the ability to remove the zona pellucida from rabbit ova.

The purposes of the present experiments were to explain the absence of TLE activity from crude acrosome extracts of ejaculated spermatozoa in view of the demonstration of TLE in epididymal spermatozoa (Stambaugh \& Buckley, 1968) and to determine the effect of capacitation on TLE activity of spermatozoa. 
Epididymal, ejaculated and capacitated spermatozoa (the last obtained by flushing the uteri of does $12 \mathrm{hr}$ after mating) were washed and treated with $0.15 \%$ Hyamine 2389 (Rohm and Haas Co.). The solution was subjected to centrifugation, precipitation with $80 \%$ alcohol, dialysis and lyophilization. Each extract was assayed using benzoyl arginine ethyl ester (BAEE) as substrate according to the method of Schwert \& Takenake (1955). One unit of TLE was defined as that amount causing a change of 0.001 optical density/min. Under these conditions, $1 \mu \mathrm{g}$ pancreatic trypsin (Worthington Biochem. Co.) has an activity of 20 units. Ejaculated sperm extracts were further purified by DEAEcolumn chromatography (Zaneveld et al., 1969).

Experiments on ova were performed by incubating $0.3 \mathrm{ml}$ of the test solution with four ova from which the cumulus had been removed by treatment with hyaluronidase.

As shown in Table 1, only one of several crude extracts of ejaculated spermatozoa showed TLE activity and this activity was very low. After fractionation and apparent removal of an inhibitor, TLE activity was present. Epididymal

\section{TABLE 1}

ACTIVITY OF VARIOUS ACROSOMAL EXTRACTS

\begin{tabular}{l|c}
\hline \multicolumn{1}{c|}{ Sperm extract } & $\begin{array}{c}\text { Units of TLE activity/mg } \\
\text { of protein }\end{array}$ \\
\hline Epididymal* & 84 to 430 \\
Ejaculated (crude)* & 0 to $10 \ddagger$ \\
Ejaculated (purified) $\dagger$ & 40 to 150 \\
Capacitated* & 80 to 130 \\
\hline
\end{tabular}

\footnotetext{
* Alcohol precipitated, dialysed and lyophilized.

$\uparrow$ After purification on DEAE column chromatography.

‡ Only one sample possessed 10 units of TLE activity, several others were not active.
}

sperm extracts always showed high TLE activity, and the TLE activity of crude extracts of the acrosomes of capacitated spermatozoa was as high as partially purified material from ejaculated spermatozoa. Five units of TLE activity (epididymal spermatozoa) was completely inhibited by $200 \mu \mathrm{g}$ soybean trypsin inhibitor. Mercaptoethanol (10 mM) gave $50 \%$ inhibition of TLE activity. To demonstate the presence of a trypsin inhibitor, boiled and centrifuged rabbit seminal plasma $(0.1 \mathrm{ml}=2.5 \mathrm{mg}$ protein) was added to 18 units of TLE from epididymal spermatozoa. This resulted in $85 \%$ inhibition of activity. Boiling was necessary to destroy the enzyme activity in seminal plasma. Crystalline serum albumin $(2.5 \mathrm{mg})$, as a non-specific control, caused only an $8 \%$ decrease in TLE activity. Different extracts of epididymal spermatozoa, as a source of TLE activity, were inhibited by various samples of heated seminal plasma. One mg of crude DF (ultracentrifuged pellet) caused only $4 \%$ reduction in activity of pancreatic trypsin (20 units). Purified DF (Robertson, Pinsker, Caster \& Williams, 1969), at $100 \mu \mathrm{g}$, did not inhibit TLE activity (15 units). Alcohol-precipitated, dialysed and lyophilized acrosomal extracts of ejaculated spermatozoa did not remove the zona pellucida from rabbit ova, 
whereas further purification by DEAE-column chromatography yielded a fraction that readily removed the zona. Zona removal, like TLE activity, was inhibited by soybean trypsin inhibitor $(200 \mu \mathrm{g})$ and mercaptoethanol $(75 \mathrm{~mm})$.

Since TLE activity is high in epididymal spermatozoa, absent in ejaculated spermatozoa and again present in capacitated spermatozoa, it is postulated that during contact with seminal plasma the TLE inhibitor is added to spermatozoa. As capacitation takes place, this inhibitor is removed. Although capacitated spermatozoa are frequently contaminated with white blood cells, these contain no trypsin-like enzymes (Zeya \& Spitznagel, 1969). Previously, Haendle, Fritz, Trautschold \& Werle (1965) and Fritz, Trautschold, Haendle \& Werle (1968) demonstrated a heat-stable polypeptide trypsin inhibitor in the seminal vesicles of mice, guinea-pigs and bulls. The existence, after contact with seminal plasma, of a TLE-inhibitor complex is analogous to the complex between corona-removing enzyme (CRE) and DF described by Zaneveld et al. (1968). It is probable that both TLE inhibitor and DF are removed during capacitation enabling the CRE and TLE to act in sequence on the corona cell layer and the zona pellucida to effect penetration of the ovum. DF did not inhibit TLE or pancreatic trypsin, indicating that the inhibitors are specific for each penetration enzyme.

Characterization of the acrosomal enzyme as trypsin-like is justified because of hydrolysis of benzoyl arginine ethyl ester at $\mathrm{pH} 8$ and inhibition by soybean trypsin inhibitor.

\section{REFERENCES}

Buruiana, L. M. (1956) Sur l'activité-hyaluronidasique et trypsinique du sperme. Naturwissenschaften, 43, 523 .

Fritz, H., Trautschold, I., Haendle, H. \& Werle, E. (1968) Chemistry and biochemistry of proteinase inhibitors from mammalian tissues. Ann. $\mathcal{N}$. r. Acad. Sci. 146, 400.

Haendle, H., Frttz, H., Trautschold, I. \& Werle, E. (1965) Über einen hormonabhangigen Inhibitor fur proteolytische Enzyme in mannlichen accessorischen Geschlechtsdrusen und im Sperma. Hoppe-Seyler's Z. physiol. Chem. 343, 185.

Hartree, E. F. \& SRivastava, P. N. (1965) Chemical composition of the acrosomes of ram spermatozoa. F. Reprod. Fert. 9, 47.

Robertson, R. T., Pinsker, M. C., Caster, W. O. \& Williams, W. L. (1969) Fractionation and properties of sperm decapacitation factor. Fedn Proc. Fedn Am. Socs exp. Biol. 28, 2, 705.

SchwerT, G. W. \& TAKenake, Y. (1955) A spectrophotometric determination of trypsin and chymotrypsin. Biochim. biophys. Acta, 16, 570 .

Srtvastava, P. N., Adams, C. E. \& Hartree, E. F. (1965) Enzymatic action of acrosomal preparations of the rabbit ovum in vitro. $\mathcal{7}$. Reprod. Fert. 10,61.

Stambaugh, R. \& Buckley, Y. (1968) Zona pellucida dissolution enzymes of the rabbit sperm head. Science, $\mathcal{N} . Y .161,585$.

Yamane, Y. (1935a) Kausel-Analytischen Studien über die Befruchtung des Kanincheneies. I. Die Dispersion des Follikelzellen und die Ablosung der Zellen der Corona Radiata des Eies durch Spermatozoen. Cytologia, 6, 128.

Yamane, Y. (1935b) Kausel-Analytischen Studien über die Befruchtung des Kanincheneies. II. Die Isolierung der auf das Eizytoplasma Auflosund Wirkunden Substanzen aus den Spermatozoen. Cytologia, 6, 474.

Zaneveld, L. J. D., MaRorie, R. A. \& Williams, W. L. (1968) A sperm enzyme that removes the corona radiata from ova and its inhibition by decapacitation factor. Fedn Proc. Fedn Am. Socs exp. Biol. 27, 567.

Zaneveld, L. J. D., McRorie, R. A. \& Williams, W. L. (1969) Enzymatic removal of the corona radiata of the ovum. Fedn Proc. Fedn Am. Socs exp. Biol. 28, 705.

ZeYa, H. I. \& Sprrznagel, J. K. (1969) Cationic protein bearing granules of polymorphonuclear leukocytes: Separation from enzyme-rich granules. Science, N.Y. 163, 1069. 